Ethiopian Journal of Environmental Studies \& Management 10(5): 566 - 571, 2017.

ISSN:1998-0507

do i: https://dx.doi.org/10.4314/ejesm.v10i5.1

Submitted: October 18, 2016

Accepted: June 02, 2017

\title{
ADEQUACY OR OTHERWISE OF CEMETERY SPACE FOR SUSTAINABLE HUMAN BODY DISPOSAL IN BENIN CITY, NIGERIA
}

\author{
*IBHADODE, C.A.E., ${ }^{1}$ DIRISU, A.R. ${ }^{2}$ AND AKHIMIEN, F.0. ${ }^{3}$ \\ ${ }^{1}$ Department of Civil Engineering, Faculty of Engineering, University of Benin, Benin \\ City, P.M.B 1154, Nigeria \\ ${ }^{2}$ Department of Animal and Environmental Biology, Faculty of Life Sciences, University \\ of Benin, Benin City, P.M.B 1154, Nigeria \\ ${ }^{3}$ Department of Geography and Regional Planning, \\ Faculty of Environmental Studies, Ambrose Alli University, Ekpoma, Edo State, Nigeria
}

\begin{abstract}
The adequacy or otherwise of cemetery space in Benin City was assessed in 2014, based on population projected from the 2006 census figures. The area of each cemetery was determined by running a Global Positioning System (GPS) traverse round each, which gave a total of $11.979 \mathrm{Ha}$. At a rate of $0.5 \mathrm{Ha}$ of cemetery space to 1000 population, for 50 years, $702.749 \mathrm{Ha}$ would be required for cemetery in Benin City. Results have shown that of these, only $1.68 \%$ is available for the teeming population of the city which comprised the three major Local Government Areas (LGAs). It is therefore recommended that cemeteries be established in new sites in each LGA, should reflect the population trends in order to achieve sustainable human body disposal in the city.
\end{abstract}

Key Words: Death, Global Positioning System, Inhabitants, Population, Sites

\section{Introduction}

Death marks the end of the life cycle of humans and other animals; and what follows is the disposal. In the present day of global emphasis on environmental sanctity and environmental sustainability, the disposal must be done in an environmentally friendly manner, in a designated place called cemetery or necropolis. Ucisik and Rushbrook (1998) reported that existing cemeteries in Benin City were sited without due consideration for the local environment and population dynamics. This is the probable reason for the scramble and ineffective utilization of the facility in Benin City. For Nigeria, Wilkie (1965) estimated the space required for cemetery to be 0.5 hectare for 1000 population for 50 years. Therefore, Benin City with a population of 1,084,676 (Census, 2006) would require 542 hectares of land for cemetery for 50 years. In 50 years, it would amount to $1,222,750$. Laws of Eastern Nigeria 1963 Vol. 2 chapter 42 section 242 as applicable in Enugu and Anambra States and other States of Nigeria, prohibits the burial of a corpse within $91.44 \mathrm{~m}$ of residential areas (WAHEB, 1991; Atsegbua et al., 2010). For human body 
disposal to be sustainable, it has to be ensured that the environmental sanctity enjoyed by the past and present inhabitants in connection with human body disposal is secured for future generations.

In cemeteries, decomposition products may cause groundwater contamination by reason of high concentration, over time, in a limited space (Corry, 1978). Cemeteries are thus places of deposits and transformations of the dead bodies without posing dangers to public health. Elsewhere in the western world and Asia including Africa, they are places of visit for those people wanting to remember a dead person and at the same time a symbol of the historical memory of a collectivity (Fogli, 2004; Uslu et al., 2009). In several parts of Benin City, residential buildings exist as close as $5 \mathrm{~m}$ to the cemetery in some cases, such as 3rd cemetery at New Benin district. The objective of this study was to determine the area of the cemetery space in Benin City with the view to matching it with the present population, in order to finding out the adequacy or otherwise of the cemetery space. Besides, the study will be of quite relevance to the concerned institutions and agencies in the policy direction to effectively manage and sustain cemeteries within Benin City. Hence, this article is very timely as there is a wide gap in the documentation of this knowledge area for quick reference purpose.

\section{Materials and Methods Study Area}

The study area was Benin City the capital of Edo State, Nigeria; comprised of three Local Government Areas: Oredo, Egor and Ikpoba-Okha and they are all located within the rain forest ecological zone within the geographical coordinates of latitudes $6^{\circ} 17^{\prime} \mathrm{N}, 6^{\circ} 26^{\prime} \mathrm{N}$ and longitudes $5^{\circ} 35^{\prime} \mathrm{E}, 5^{\circ} 41^{\prime} \mathrm{E}$. It has an annual mean temperature of $27.5{ }^{\circ} \mathrm{C}$ (Ikhuoria, 1987) and an annual mean rain fall of about $2095 \mathrm{~mm}$ (Ikhile and Olorode, 2011). Schools, hospitals, markets and three cemeteries are among the social services provided in the city. 


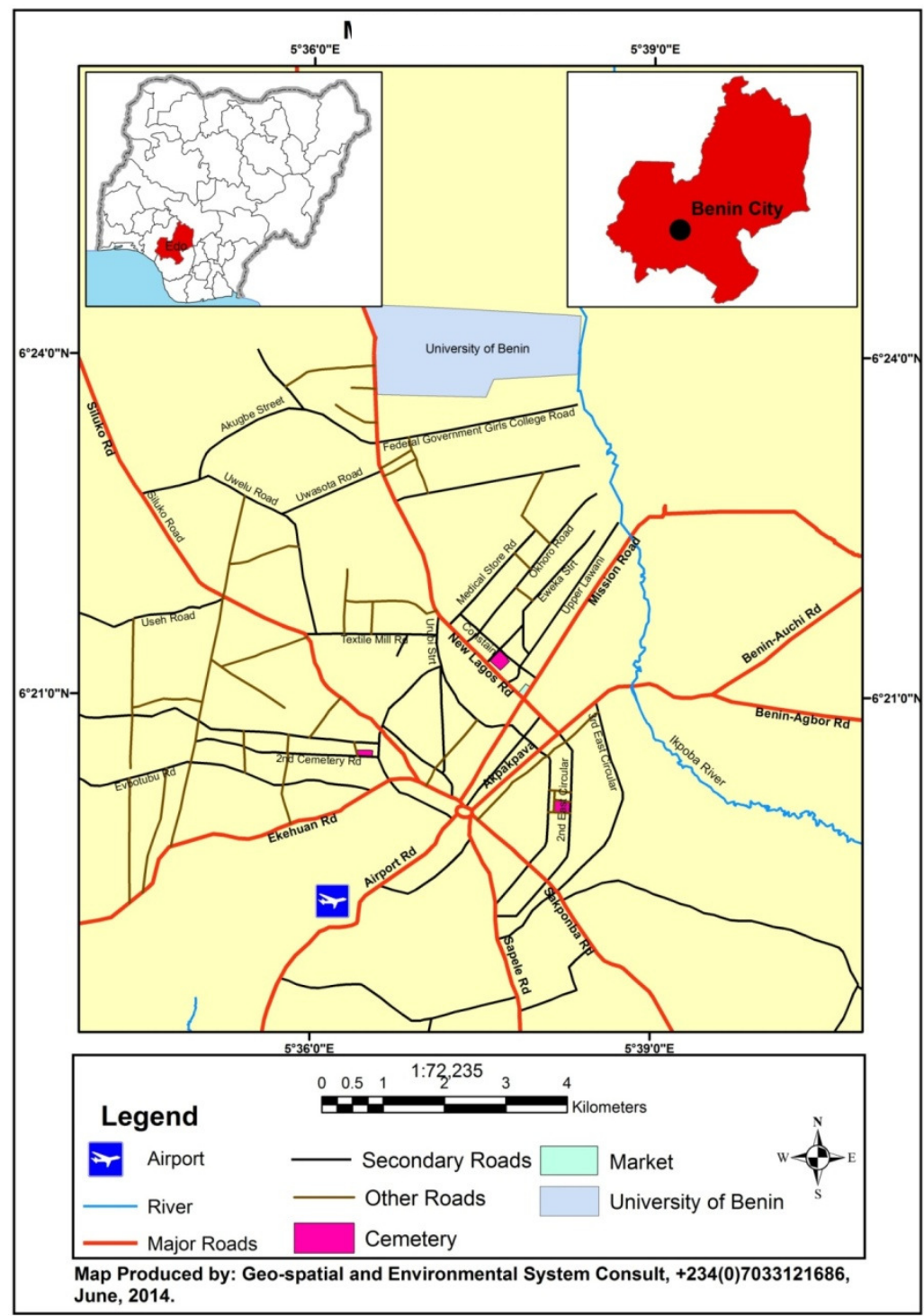

Fig. 1: Map of the Study Area in Benin City, Nigeria

\section{Area Determination}

The areas of the cemeteries were determined by running a hand-held Global Positioning System (GPS) (Garmin eTrex H Personal Navigator) by traversing round the boundaries of each cemetery. Each cemetery boundary point was designated as Way Point (WP) and the rectangular coordinates of each point at each cemetery were taken (Table 1).
From the coordinates the area of each cemetery was computed.

\section{Population of Benin City}

The population of Benin City by Local Government Area (LGA) for 2006 Population Census was obtained from the State Office of National Population Commission in Benin City (Table 2). Population projection model, crudedeath-rate and population growth rate figures were obtained from the Federal 
Office of Statistics, Benin City. Population Projection Model:

$$
\mathrm{X}=\mathrm{p}(1+\mathrm{r} / 100)^{\mathrm{t}}
$$

Where $\chi=$ projected population

$\mathrm{p}=$ population of base year

$\mathrm{r}=$ population growth rate (3.2)

$\mathrm{t}=$ intervening years

\section{Results and Discussion}

Computation of the area of each cemetery from the coordinates obtained with the GPS, gave a total of 11.797 hectares (Ha) (see table 1). The individual cemeteries include; First Cemetery, 4.287 Ha, Second Cemetery, 2.343 Ha and Third Cemetery, 5.167 Ha as they were respectively named as their time of establishment. Investigation has revealed that the three cemeteries in the city are all located in Oredo LGA. It would take the inhabitants at the fringes of Egor LGA, like Ugbowo, up to 2.5 $\mathrm{Km}$ to get to the cemetery nearest to them at New Benin. It would as well take the people of Ikhueniro in Ikpoba-Okha LGA about $5 \mathrm{Km}$ to get to the cemetery closest to them at Second East Circular axis. The problem was further compounded by heavy vehicular traffic on the roads, occasioned by bad roads. These could be among the reasons that some people resort to burying their dead ones within their compounds in Benin City.

The population of Benin City stood at 1085676 , by 2006 population census. It came to $1,396,81$, when projected to 2014, the year of the study. (Table 2) The intervening years between 2006 and 2014 was 8 years.

From Table 2, it can be seen that the space required for cemetery in Oredo local government area in 2014 was $241.023 \mathrm{Ha}$, whereas only $11.797 \mathrm{Ha}$ was available amounting to $4.86 \%$. Egor
LGA required $238.729 \mathrm{Ha}$ of land for cemetery in 2014 but the space available was zero. Ikpoba-Okha LGA required 218.654 Ha but the space available was also zero. On the whole, $698.406 \mathrm{Ha}$ of land was required for cemetery in Benin City in 2014, whereas only $11.797 \mathrm{Ha}$ was available, representing a paltry quantity of $1.69 \%$. This is quite out of tune with the population of Benin City as at 2014. Therefore, gross inadequacy of cemetery space in Benin City had been revealed in this study. If the population was projected to $2020(1,687,392)$, the area required for cemetery in Benin City would amount to $843.696 \mathrm{Ha}$. In a similar study, Ucisik and Rushbrook (1998) observed in Australia that existing cemeteries were sited without due regard to population and other environmental variables. This shortcoming resulted in inadequacy of cemetery space with respect to current population in Australia.

With a crude death rate of 17.4, 18,891 dead bodies are expected in Benin City annually as it applied in the year 2014. If all the dead are buried in new graves of $2.16 \mathrm{~m}^{2}$ (Wilkie, 1965), it would take just 2.94 years for all the cemetery space in Benin City to be exhausted. (Time taken $=$ Space available $\left(\mathrm{m}^{2}\right) /$ No. of dead bodies $\chi$ Grave size $\left(\mathrm{m}^{2}\right)$ years).

Continued burial of the dead in such a limited cemetery space could result in high concentration of decomposition products, which over time can endanger the groundwater beneath (Corry, 1978).

A look around Benin City reveals that the presence of graves in residential areas was in defiance of the environmental laws prohibiting such burial. This practice could have been influenced by the long distances of some districts and 
quarters within the city to the cemetery, or by some cultural undercurrent prevailing in the area. It is therefore recommended that a standard cemetery should be established in each of the Local
Government Areas with due consideration to distance to users and the population of the inhabitants among other factors.

Table 1: Benin City Cemeteries and their Areas

\begin{tabular}{|c|c|c|c|c|c|}
\hline Name & Location & $\begin{array}{l}\text { Coordinates } \\
(\mathrm{m}) \\
\text { Northing }(\mathrm{X})\end{array}$ & $\begin{array}{l}\text { Coordinates } \\
\text { (m) } \\
\text { Easting (Y) }\end{array}$ & $\begin{array}{l}\text { Name of } \\
\text { Point }\end{array}$ & Area $(\mathrm{Ha})$ \\
\hline \multirow{2}{*}{\multicolumn{5}{|c|}{ Cemetery }} & \\
\hline & & & 356483 & $\mathrm{WP}_{2}$ & \\
\hline & & 258181 & 356491 & $\mathrm{WP}_{3}$ & \\
\hline & & 258150 & 356735 & $\mathrm{WP}_{4}$ & 4.287 \\
\hline \multirow[t]{4}{*}{ Sec. Cemetery } & & 258968 & 353249 & $\mathrm{WP}_{5}$ & \\
\hline & & 258968 & 353520 & $\mathrm{WP}_{6}$ & \\
\hline & & 258877 & 353522 & $\mathrm{WP}_{7}$ & \\
\hline & & 258877 & 353278 & $\mathrm{WP}_{8}$ & 2.343 \\
\hline \multirow{2}{*}{\multicolumn{6}{|c|}{ Cemetery }} \\
\hline & & & & & \\
\hline & & 260619 & 355566 & $\mathrm{WP}_{10}$ & \\
\hline & & 260492 & 355714 & $\mathrm{WP}_{11}$ & \\
\hline & & 260287 & 355585 & $\mathrm{WP}_{12}$ & 5.167 \\
\hline Total & & & & & 11.797 \\
\hline
\end{tabular}

Table 2: Population of Benin City by Local Government Area and Cemetery Space

\begin{tabular}{llllll}
\hline $\begin{array}{l}\text { Local } \\
\text { Government }\end{array}$ & $\begin{array}{l}2006 \\
\text { Area }\end{array}$ & $\begin{array}{l}2014 \\
\text { Population } \\
\text { Pojected }\end{array}$ & $\begin{array}{l}\text { Cemetery } \\
\text { Space } \\
\text { Available } \\
\text { (Ha) }\end{array}$ & $\begin{array}{l}\text { Cemetery } \\
\text { Space } \\
\text { Required } \\
\text { (Ha) }\end{array}$ & $\begin{array}{l}\text { Percentage } \\
\text { Availability } \\
(\%)\end{array}$ \\
\hline Oredo & 374671 & 482045 & 11.797 & 241.023 & 4.89 \\
Egor & 371106 & 477458 & 0 & 238.729 & 0 \\
Ikpoba-Okha & 339899 & 437308 & 0 & 218.654 & 0 \\
Total & 1085676 & 1396811 & 11.797 & 698.406 & 1.69 \\
\hline
\end{tabular}

\section{Conclusion}

Benin City cemeteries currently standing at $11.797 \mathrm{Ha}$, with $1.7 \%$ space availability needs to be drastically expanded. The fact that they are now located in built-up areas of the city would make the expansion in the old sites difficult. They need to be relocated to new sites, by Local Government Area managements for easy accessibility by the users. Population of the inhabitants, standard distance from human residence, soil geology and hydrogeology, among other factors must be considered in the sitting to ensure environmental sustainability. 


\section{References}

Atsegbua, L., Akpotourie, V., Dimowo, F. (2010). Environmental Law in Nigeria: Theory and Practice. Ambik Press, Benin City, 555pp.

Corry, J.E.L. (1978). Post-mortem ethanol production. Journal of Applied Bacteriology, 44: 1 - 48.

Fogli, D. (2004). Techniques of decomposition of Bodies Adopted in Cemeteries and Their Relations with the Environment, available at http://

6.71.151.103/effs/docs/shangai_ing

Ikhile, C.I. and Oloriode, D.O. (2011). Impact of climate change on underground-water resources development in Benin-Owena river basin, Edo State, Nigeria: case study. European Journal of Scientific Research 63(2): 272 278.

Ikhuoria, I.A. (1987). Urban land use patterns in traditional Nigeria City: A case study of Benin City. Land use policy, Great Britain, 4 (1): 62 75.

National Population Commission (2006). Federal Republic of Nigeria Official Gazette 24 (94), Lagos Nigeria.
Sililo, O.T.N. and Saayman, I.C. (2001). Groundwater vulnerability to pollution in urban catchment. Report to the Water Research Commission South Africa Project No. 1008/1/01

Ucisik, A.S. and Rushbrook, P. (1998). The impact of cemeteries on the environment and public health: an introductory briefing. Waste Management WHO Regional Office for Europe, Nancy Project Office, Copenhagen, Denmark.

Uslu, A., Baris, E. and Edogan, E. (2009). Ecological Concerns over Cemetery. African Journal of Agricultural Research, 4(13): 1505 - 1511.

West Africa Health Examinations Board (1991). Waste Disposal and Environmental Hazard Control. Published by West Africa Health Examinations Board 72 Campbell Street, Lagos.

Wilkie, W. (1965). Jordan Tropical Hygiene and Sanitation. Lond (Bailhiere, Tindall and Cox). 